\title{
SPEED OF AUTUMN MIGRATION OF THE BLUE TIT (Parus caeruleus) ALONG THE EASTERN AND SOUTHERN BALTIC COAST
}

\author{
Jarosław K. Nowakowski and Jacek Chruściel
}

\begin{abstract}
Nowakowski J.K., Chruściel J. 2004. Speed of autumn migration of the Blue Tit (Parus caeruleus) along the eastern and southern Baltic coast. Ring 26, 1: 3-12.

An analysis of the speed of autumn migration was based on 315 ringing recoveries of Blue Tits caught between 1963-1999 at 6 ringing stations along the south-eastern and southern Baltic coast. It was found that among passerines the Blue Tit is the slowest European migrant (median value $-25.8 \mathrm{~km} /$ day, average $-28.4 \mathrm{~km} /$ day), with a very low (intra- and interpopulation) variation of migration speed. No differences in migration speed were found between individuals of different age and sex and among years of different intensities of movements. The migration speeds of the Blue Tit and the Great Tit (Parus major) in different years correlated.
\end{abstract}

J.K. Nowakowski, Dept. of Zoology, University of Podlasie, Prusa 12, PL-08-110 Siedlce, Poland; Bird Migration Research Station, University of Gdańsk, Przebendowo, PL-84-210 Choczewo, Poland, E-mail: sikorka1965@tlen.pl; J. Chruściel, Dept. of Zoology, University of Podlasie, Prusa 12, PL-08-110 Siedlce, Poland

Publication appointed to the SE European Bird Migration Network papers

Key words: migration speed, partial migration, Blue Tit, Parus caeruleus

\section{INTRODUCTION}

Until recently, the central, northern and eastern European populations of four species of tits - the Great Tit (Parus major), Blue Tit, Willow Tit (Parus montanus) and Coal Tit (Parus ater) - were considered typical irruptive migrants (for terminology see Nowakowski and Vähätalo 2003). They were thought to have very variable parameters of migration, in particular, considerable fluctuation in the numbers of birds migrating over Europe from year to year (Ulfstrand 1962, Alerstam 1993, Berthold 1993, Cramp and Perrins 1993, Glutz von Blotzheim and Bauer 1993). The speed of their movement, distance and direction have also been regarded as highly variable when comparing years as well as individuals in the same year (Glutz von Blotzheim and Bauer 1993). However, it has been recently proved that Great and 
Blue Tits migrate every year in relatively stable numbers in northern, central and eastern Europe, thus - in opposition to Willow and Coal Tits - they are typical, regular, partial migrants in this region (Nowakowski and Vähätalo 2003). It has been shown that the Great Tit's passage was relatively uniform over large areas (Nowakowski 2002, 2003). Greater deviations from the normal direction of movement were noted mainly when strong unfavourable winds were present, as occurs with other species of regular migrants (Lindholm 1978, Alerstam 1993, Nowakowski 2003). Moreover, it appeared that the Great Tit was a species of very low variation in migration speed in relation to both regular - Robin (Erithacus rubecula), and irregular migrants - Siskin (Carduelis spinus) (Nowakowski 2001). The results presented in the cited paper suggest that the Blue Tit exhibits an even lower variation of migration speed than the Great Tit. These conclusions, however, were based on a limited data - only 19 individuals (Nowakowski 2001).

The aim of this paper is to determine whether the Blue Tit, as the Great Tit, has a low variation of migration speed (considering spatial and temporal variation and differences between age and sex classes), or whether its migration pattern is more representative of an irregular migrant, such as the Coal Tit or Siskin.

\section{METHODS}

The migration speed was determined by calculating the difference between the ringing and recovery dates of 320 Blue Tits. The source of this data was based on bird movements between ringing stations in Sôrve $\left(57^{\circ} 76^{\prime} \mathrm{N}, 22^{\circ} 03^{\prime} \mathrm{E}\right.$ - Estonia), Kabli $\left(58^{\circ} 01^{\prime} \mathrm{N}, 24^{\circ} 27^{\prime} \mathrm{E}\right.$ - Estonia), Pape (56 $11^{\circ} \mathrm{N}, 21^{\circ} 03^{\prime} \mathrm{E}$ - Latvia), Neringa

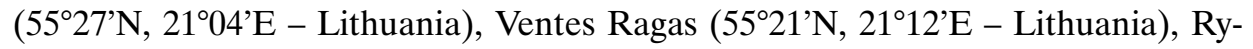
bachy $\left(55^{\circ} 09^{\prime} \mathrm{N}, 2^{\circ} 52^{\prime} \mathrm{E}\right.$ - Russia, Kaliningrad region), Mierzeja Wiślana $\left(54^{\circ} 21^{\prime} \mathrm{N}\right.$,

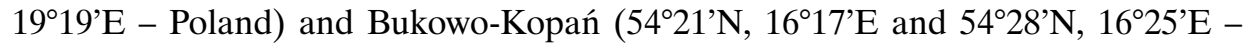
Poland) - a total of 293 ringing recoveries (Table 1). In addition, recoveries of birds ringed in stations at Sôrve, Kabli, Neringa and Rybachy and recorded elsewhere were also used - a total of 27 recoveries. For a description of habitats, methods of fieldwork and location of the stations see Busse (2000) and Nowakowski (2001). All the data came from bird ringing reports published in Estonia, Lithuania and by the Rybachy ringing station (Kastepõld 1971, 1972, 1973, 1974, 1975; Kumari and Jogi 1974; Kastepõld and Kabal 1976, 1977, 1978, 1980, 1981, 1982, 1983, 1984, 1985a, 1985b; Patapavičius 1982, 1983, 1986a, 1986b, 1986c, 1987, 1988, 1989; Kastepõld and Kastepõld 1987a, 1987b, 1988, 1990a, 1990b, 1991, 1992, 1993, 1994; Skuodis and Kurpyté 1989; Bolshakov et al. 1999; Bolshakov et al. 2001).

To calculate the mean intensity of autumn migration in the region (IMR-index), the number of birds caught in stations at Sôrve (in years 1978-1990), Kabli (1971-1996), Pape (1967-1996), Neringa (1980-1996), Ventes Ragas (1980-1996), Rybachy (1967-1995) and Mierzeja Wiślana (1967-1996) were used.

Only recoveries of birds ringed and recaptured between 10 September and 10 November of the same year were used in the analysis of migration speed. This pe- 
Table 1

Numbers of ringing recoveries used in the study

\begin{tabular}{|l|c|c|c|c|c|}
\hline \multirow{2}{*}{ Place of recovery } & \multicolumn{5}{|c|}{ Ringing station } \\
\cline { 2 - 6 } & Sôrve & Kabli & Neringa & $\begin{array}{c}\text { Ventes } \\
\text { Ragas }\end{array}$ & Rybachy \\
\hline Pape & 21 & 21 & - & - & - \\
\hline Neringa & 22 & 24 & $\times$ & - & - \\
\hline Ventes Ragas & 11 & 27 & - & $\times$ & - \\
\hline Rybachy & 10 & 33 & - & - & 28 \\
\hline Mierzeja Wiślana & 1 & 5 & 34 & 17 & 18 \\
\hline Bukowo-Kopań & - & 4 & 8 & 9 & 21 \\
\hline Other locations & 3 & 1 & 2 & $\mathbf{6 7}$ \\
\hline Total & $\mathbf{6 8}$ & $\mathbf{1 1 5}$ & $\mathbf{4 4}$ & $\mathbf{2 6}$ & $\mathbf{6}$ \\
\hline
\end{tabular}

riod covers the entire migration season of the Blue Tit (Glutz von Blotzheim and Bauer 1993). Movements slower than $10 \mathrm{~km} /$ day and for a distance less than $130 \mathrm{~km}$ were excluded from the analysis. Birds that moved with a speed below $10 \mathrm{~km} /$ day accounted for as little as $2 \%$ of all recoveries and probably represented individuals that had not yet started migrating when ringed. With the adopted method of calculating migration speed, movements for distances shorter than $130 \mathrm{~km}$ resulted in a systematic bias, lowering the median and the average. Also, 8 recoveries from Sweden and Denmark were excluded from the analysis, as these birds had to cross the sea for at least part of this distance (for a wider discussion of methods used see Nowakowski 2001).

A preliminary analysis showed that Blue Tits ringed between 10 and 14 September moved significantly slower than those caught later (10-14 Sep.: median $=$ $19.8 \mathrm{~km} /$ day, mean $=18.7 \mathrm{~km} /$ day, $N=5$; after 14 Sep.: median $=25.8 \mathrm{~km} /$ day, mean $=28.4 \mathrm{~km} /$ day, $N=315 ; U$-test: $Z=2.09, p=0.036)$. Thus, it may be that at least some of the birds ringed before the beginning of September had not begun migration yet. Similarly, Great Tits ringed between 10 and 14 September presented a remarkably slower migration speed than those ringed after 14 September (Nowakowski 2001). Therefore, in further analyses, only 315 recoveries of Blue Tits ringed after 14 September were used.

To analyse changes in the migration speed between 1963 and 1999, the year was correlated with the mean speed of migration during that year. However, in some years the data consisted of only 1,2 or 3 recoveries fulfilling the criteria described above. In such cases, the migration speed was calculated based on ringing recoveries from that and the following year (if this was not possible, then from the 
preceding year), and the independent variable was given a value calculated by the formula:

$$
Y=X+\frac{N_{x+1}}{N_{x}+N_{x+1}}
$$

where:

$X$ - the number of the first of the two years for which the mean speed was calculated,

$N_{x}$ - the number of recoveries in year $X$,

$N_{x+1}$ - the number of recoveries in the following year.

For example, if in 1974 two ringing recoveries were noted and in 1975 - ten recoveries, then the mean migration speed was calculated for the twelve recoveries jointly and the independent variable was set as $1974.83(=1974+10 / 12)$. When correlating the mean migration speeds of the Great Tit and the Blue Tit for subsequent years, the years where only a single recovery was available for one of the species were excluded.

In the analyses of changes of migration speed between 15 September and 24 October, only these recoveries were used where the difference between the dates of ringing and recovery was 15 days or less.

To check whether there was any relation between the intensity of the autumn migration and its speed, the mean intensity of migration in the region (IMR-index) was calculated for each year (from 1967 to 1996). IMR-index describes the mean intensity of migration in a given autumn in the region between Estonia and north-eastern Poland. It is calculated as the mean number of birds caught at ringing stations located in this area in relation to multi-year averages of the numbers of birds caught at these stations (for formulas see Nowakowski and Vähätalo 2003, for a discussion of methods see Nowakowski 2003). The IMR-index is expressed as a percent value. The mean from 1980-1996 was accepted as the reference value, as most stations were operating then (Sôrve, Kabli, Pape, Neringa, Ventes Ragas, Rybachy, Mierzeja Wiślana). The mean IMR-index for this period is 100\%. In 1967-1996 IMR-index ranged from $28 \%$ to $170 \%$. All ringing recoveries were grouped in 29 ranges (equal to $5 \% I M R$ ) of the span (the first IMR range $-25 \%$ to $30 \%$, the last IMR range $165 \%$ to $170 \%$ ). The independent variable was the middle of a given range (for the first range $-27.5 \%$ ), the dependent variable was the median or the mean value of the migration speed calculated for all recoveries of years with an IMR-index within a given range.

Altogether 981 ringing recoveries of the Great Tit were used for the statistical comparisons. This data also served as the basis for the earlier analysis of this species' migration speed (Nowakowski 2001). These recoveries are from the same period as those used in the present paper, refer to birds ringed at the same stations and the data was initially selected using the same criteria as applied here (a minimum distance of $130 \mathrm{~km}$ between stations, exclusion of birds moving over the sea to Sweden and Denmark, exclusion of birds ringed before 15 September - see Nowakowski 2001). Therefore, the parameters of the Great Tit migration presented 
in the cited paper can be compared directly with the parameters of the Blue Tit migration described in the present study.

The following abbreviations and symbols were used in the study: imm. - immature, first-year bird; $a d$. - adult, bird older than first-year; $M_{d}$ - median; $m$ - average; $r_{s}$ - Spearman rank correlation coefficient; $p<0.001$ - probability between 0.001 and $0.0001 ; p<<0.001-$ probability below 0.0001 .

\section{RESULTS}

Blue Tits migrated slightly slower than Great Tits (Blue Tit: $M_{d}=25.8 \mathrm{~km} / \mathrm{day}$, $m=28.4 \mathrm{~km} /$ day, $N=315$; Great Tit: $M_{d}=29.3 \mathrm{~km} /$ day, $m=33.2 \mathrm{~km} /$ day, $N=891 ; U$-test: $Z=4.93, p<<0.001)$ and had a relatively low variation of migration speed - lower than that of the Great Tit ( $F$-test: $F=1.86, p<<0.001$; Fig. 1). In Blue Tits, $70 \%$ moved with a speed in the range of 16.2-39.6 km/day, while respectively Great Tits were in the range of $18.4-44.3 \mathrm{~km} /$ day.

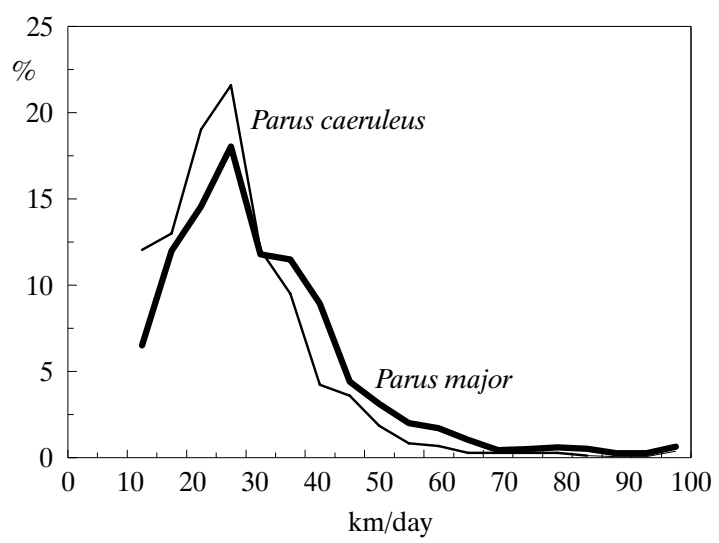

Fig. 1. Distribution of the migration speed values of Blue Tits and Great Tits.

No statistically significant differences in migration speed were found between Blue Tits of different sexes ( $0: M_{d}=25.4 \mathrm{~km} /$ day, $m=26.9 \mathrm{~km} /$ day, $N=77$; P: $M_{d}=26.6 \mathrm{~km} /$ day, $m=29.3 \mathrm{~km} /$ day, $N=128$; $U$-test: $\left.Z=0.96, p=0.335\right)$ or of different ages ( $a d:: M_{d}=24.7 \mathrm{~km} /$ day, $m=28.2 \mathrm{~km} /$ day, $N=61$; imm.: $M_{d}=25.8 \mathrm{~km} /$ day, $m=28.2 \mathrm{~km} /$ day, $N=202 ; U$-test: $Z=1.00, p=0.316$ ).

The migration speed of the Blue Tit was compared between two sections of their route of movement: (1) north-eastern (NE section) - recaptures were from stations at Neringa, Ventes Ragas or Rybachy $\left(c a 55^{\circ} \mathrm{N}\right.$ and $\left.c a 20^{\circ} \mathrm{E}\right)$ or from the area to the northeast of these stations; (2) south-western (SW section) - a bird was ringed in one of stations at Neringa, Ventes Ragas or Rybachy and recaptured to the southwest of these stations. No differences were found between the two route sections (for NE section: $M_{d}=25.4 \mathrm{~km} /$ day, $m=28.4 \mathrm{~km} /$ day, $N=169$; for $\mathrm{SW}$ section: $M_{d}=25.8 \mathrm{~km} /$ day, $m=28.4 \mathrm{~km} /$ day, $\left.N=135\right)$. 
Table 2

Changes of migration speed of the Blue Tit during the course of autumn passage

\begin{tabular}{|l|c|c|c|}
\hline \multicolumn{1}{|c|}{ Ringing date } & Median (km/day) & Mean (km/day) & $N$ \\
\hline 15-24 Sep. & 25,6 & 27,8 & 32 \\
\hline 25 Sep.-4 Oct. & 29,7 & 30,6 & 95 \\
\hline 5-14 Oct. & 27,6 & 31,0 & 84 \\
\hline 15-24 Oct. & 31,3 & 38,4 & 23 \\
\hline
\end{tabular}

As the season progressed, the migration speed of the Blue Tit increased slowly (Table 2). No movements quicker than $55 \mathrm{~km} /$ day $(N=100)$ were noted in September, while in October they amounted to $7 \%$ of the total $\left(N=136 ; \chi^{2}\right.$-test with Yates correction: $\chi^{2}=5.97, p=0.015$ ).

Between 1963 (the first year of data used) and the mid-1970s, the mean migration speed increased (Spearman rank correlation for 1963-1975: $r_{s}=0.82, p=0.007$, $N=9)$. It reached its maximum speed in the years $1974-1975\left(M_{d}=32.5 \mathrm{~km} /\right.$ day, $m=37.7 \mathrm{~km} /$ day, $N=12 ;$ Fig. 2). Since that time, a decrease in the migration speed has been observed (for 1974-1999: $r_{s}=-0.66, p=0.011, N=14$ ). The pattern of changes in migration speed could be also described as a high speed of movements in the 1970s with a relatively low speed in the remaining years (in years 1971-1979: $M_{d}=32.0 \mathrm{~km} /$ day, $m=35.1 \mathrm{~km} /$ day, $N=69$; the remaining years: $M_{d}=25.5 \mathrm{~km} /$ day, $m=26.5 \mathrm{~km} /$ day, $N=246$; $U$-test: $Z=3.90, p<<0.001$; Fig. 2). A similar general pattern of migration speed was revealed earlier in the Great Tit (Nowakowski 2001). In total, no significant change in the migration speed was noted in the Blue Tit for the period 1963-1999 $\left(r_{s}=-0.25, p=0.264, N=22\right)$. Mean migration speeds of the Blue and the Great Tits in subsequent years were positively correlated $\left(r_{s}=0.63, p=0.002, N=21\right.$; Fig. 3).

Between 1967-1996, the intensity of the Blue Tit migration in the region (IMR-index) ranged from $28 \%$ to $170 \%$ of the multi-year average (see Methods) and was

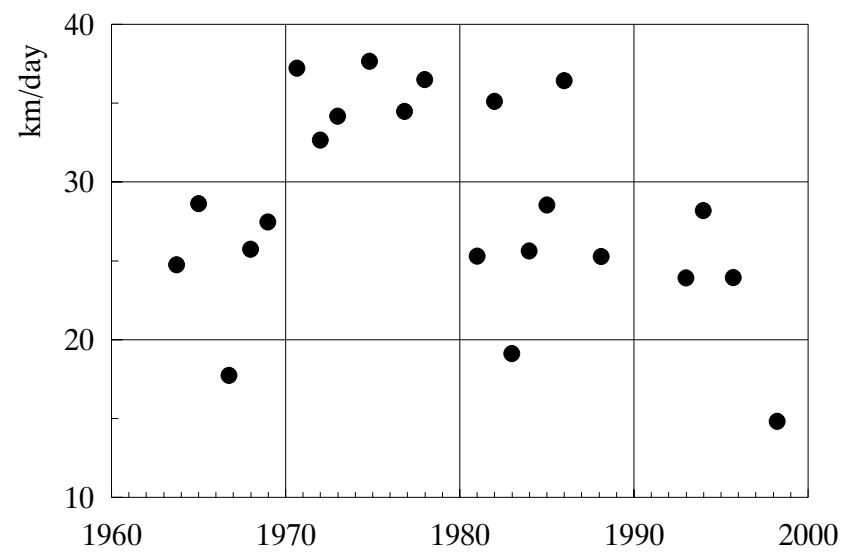

Fig. 2. Average migration speed of the Blue Tit observed in the years 1963-1999 


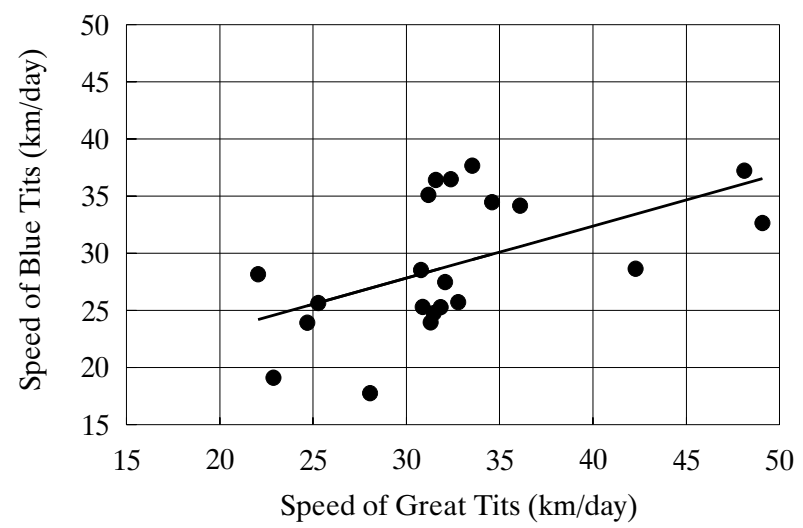

Fig. 3. Relations between average speed of the Blue Tit and the Great Tit in different years

not correlated with the migration speed of a given year (for medians: $r_{s}<0.01$, $p=0.974, N=16$; for means: $r_{s}=0.05, p=0.846, N=16$ ). This means that years of intensive passage were not outstanding with respect to the speed of movements.

\section{DISCUSSION}

The results obtained confirmed that the Blue Tit is the slowest migrant among tits and in general the slowest migrant among European passerines (Rute 1976, Hildén and Saurola 1982, Nowakowski 2001). This is apparently associated with its way of migrating, typical for all tits - usually during the day, in small jumps from bush to bush (Ulfstrand 1962, Frelin 1979). Among European tits, beside the Blue Tit only the slightly larger Great Tit is a regular partial migrant. The mean length of the folded wing (for the measurement technique see Busse 2000) for 5938 Blue Tits measured at the Mierzeja Wiślana station for the period of 1984-1997 was 66.46 $\mathrm{mm}$, while for 11228 Great Tits it was respectively $75.68 \mathrm{~mm}$ (i.e. $13.9 \%$ longer). Medians of the wing length cannot be calculated as precisely due to the character of the data, but the distribution of the wing length is normal, so that the median equals the average. Thus, it may be assumed that median values of the wing length also differed between these species by $13.9 \%$. If we compare medians of the migration speed, it appears that Great Tits migrate $13.6 \%$ quicker than Blue Tits. This means that both species migrate with exactly the same speed in relation to their body size!

Compared with other species, the Blue Tit presents a very low variation of migration speed among different individuals - smaller than in other species of shortdistance migrants (Nowakowski 2001). As with the Great Tit (op. cit.), no differences in migration speed were found among individuals of different age and sex in the Blue Tit. In the present study, no differences in migration speed were revealed between the routes from Estonia to Lithuania and from Lithuania to Poland and further to Western Europe. Values of the migration speed given by other authors are usually based on very limited samples, but generally they do not depart 
from the ones presented here: for Switzerland (Frelin 1979) $-M_{d}=24.0 \mathrm{~km} /$ day, $m=29.0 \mathrm{~km} /$ day, $N=11$; for birds arriving to the Netherlands (Balen and Speek 1976) - range $=37.9-45.4 \mathrm{~km} /$ day, $m=41.4 \mathrm{~km} /$ day, $N=4$. A lower migration speed $(m=12 \mathrm{~km} /$ day, $N=10)$ for Finnish populations was provided by Hildén and Saurola (1982), but these authors included movements with a speed below $10 \mathrm{~km} /$ day and for a distance below $100 \mathrm{~km}$ in their analyses. If the same criteria of data selection were applied to the data analysed by Hildén and Saurola (1982), the mean speed for the Finnish Blue Tits would be $c a 20 \mathrm{~km} /$ day. These facts allow us to state that geographical variation for the migration speed of the Blue Tit in Europe is also very low.

No multi-year trend in changes of the migration speed was revealed, however some differences among years were noted. These fluctuations were correlated between the Blue and the Great Tit, which means that faster or slower migration rates occurred in both species in the same years. For both species, these changes, however, were not related to the intensity of passage (for the Great Tit see Nowakowski 2001). They may result from weather conditions during a given autumn (they probably depend mainly on the speed and direction of the wind and also on the temperature). Both species migrate approximately at the same time, i.e. in the second half of September and in October (Glutz von Blotzheim and Bauer 1993), thus changes of weather conditions affect the parameters of their migration similarly. In contrast, the intensity of migration depends on population factors - most probably on the autumnal densities of a population (Berthold 1993).

The very low variation of migration speed (both intra- and inter-population), the lack of relationship between the intensity of migration and its speed, as well as the character and size of multi-year fluctuations in numbers (Nowakowski and Vähätalo 2003) confirm that the Blue Tit, as is the case with the Great Tit, is a regular, partial migrant with no inclination to conducting invasions.

\section{REFERENCES}

Alerstam T. 1993. Bird Migration. Cambridge Univ. Press, Cambridge.

Balen J.H., Speek B.J. 1976. An irruption of Tits (Paride) in the autumn of 1971. Limosa 49: 188-200.

Berthold P. 1993. Bird Migration: a general survey. Oxford Univ. Press, Oxford.

Bolshakov C.V., Shapoval A.P., Zelenova N.P. 1999. Results of bird trapping and ringing by the Biological Station "Rybachy" on the Courish Spit in 1998. Avian Ecol. Behav. 2: 105-150.

Bolshakov C.V., Shapoval A.P., Zelenova N.P. 2001. Results of bird ringing by the Biological Station "Rybachy" on the Courish Spit: long-distance recoveries of birds ringed in 1956-1997. Avian Ecol. Behav., Suppl. 2: 1-150.

Busse P. (Ed.). 2000. Bird station manual. SE European Bird Migration Network, Univ. of Gdańsk, Gdańsk.

Cramp S., Perrins C.M. (Eds). 1993. Handbook of the Birds of Europe, the Middle East and North Africa. The Birds of the Western Palearctic. vol. 7. Oxford Univ. Press, Oxford - New York.

Frelin Ch. 1979. Physiological adaptation of Blue Tits (Parus caeruleus) to migration. Vogelwarte 30:33-41.

Glutz von Blotzheim U.N., Bauer K.M. (Eds). 1993. Handbuch der Vögel Mitteleuropas. vol. 13/I, AulaVerlag, Wiesbaden: pp. 600-608, 720-737.

Hildén O., Saurola P. 1982. Speed of autumn migration of birds ringed in Finland. Ornis Fenn. 59: 140-143. 
Kastepõld T. 1971. Estonia Matsalu 1970. Loodusvaatlusi II.

Kastepõld T. 1972. Estonia Matsalu 1971. Loodusvaatlusi II.

Kastepõld T. 1973. Estonia Matsalu 1972. Loodusvaatlusi II.

Kastepõld T. 1974. Estonia Matsalu 1973. Rõngastusaruanne nr. 4. Loodusvaatlusi II.

Kastepõld T. 1975. Estonia Matsalu 1974. Rõngastusaruanne nr. 5. Loodusvaatlusi II.

Kastepõld T., Kabal R. 1976. Estonia Matsalu 1975. Rõngastusaruanne nr. 6. Loodusvaatlusi II.

Kastepõld T., Kabal R. 1977. Estonia Matsalu 1976. Rõngastusaruanne nr. 7. Loodusvaatlusi II.

Kastepõld T., Kabal R. 1978. Estonia Matsalu 1977. Rõngastusaruanne nr. 8. Loodusvaatlusi II.

Kastepõld T., Kabal R. 1980. Estonia Matsalu 1978. Rõngastusaruanne nr. 9. Loodusvaatlusi II.

Kastepõld T., Kabal R. 1981. Estonia Matsalu 1979. Rõngastusaruanne nr. 10. Loodusevaatlusi II.

Kastepõld T., Kabal R. 1982. Väljaspool Eestit NSV-d rõngaststud lindude taasleiud Eesti NSV-s 1956-1980. Tallin.

Kastepõld T., Kabal R. 1983. Estonia Matsalu 1980. Rõngastusaruanne nr. 11. Loodusevaatlusi II.

Kastepõld T., Kabal R. 1984. Estonia Matsalu 1981. Rõngastusaruanne nr. 12. Loodusevaatlusi II.

Kastepõld T., Kabal R. 1985a. Estonia Matsalu 1982. Rõngastusaruanne nr. 13. Loodusevaatlusi II.

Kastepõld T., Kabal R. 1985b. Estonia Matsalu 1983. Rõngastusaruanne nr. 14. Loodusevaatlusi II.

Kastepõld T., Kastepõld E. 1987a. Estonia Matsalu 1984. Rõngastusaruanne nr. 15. Loodusevaatlusi II.

Kastepõld T., Kastepõld E. 1987b. Estonia Matsalu 1985. Rõngastusaruanne nr. 16. Loodusevaatlusi II.

Kastepõld T., Kastepõld E. 1988. Estonia Matsalu 1986. Rõngastusaruanne nr. 17. Loodusevaatlusi II.

Kastepõld T., Kastepõld E. 1990a. Estonia Matsalu 1987. Rõngastusaruanne nr. 18. Loodusevaatlusi II.

Kastepõld T., Kastepõld E. 1990b. Estonia Matsalu 1988. Rõngastusaruanne nr. 19. Loodusvaatlusi II.

Kastepõld T., Kastepõld E. 1991. Estonia Matsalu 1989. Rõngastusaruanne nr. 20. Loodusvaatlusi II.

Kastepõld T., Kastepõld E. 1992. Väljaspool Eestit Rõngastatud lindude taasleiud Eestis 1981-1990. Matsalu Riiklik Looduskaitseala, Tallin.

Kastepõld T., Kastepõld E. 1993. Estonia Matsalu 1992. Rõngastusaruanne nr. 23. Loodusvaatlusi II.

Kastepõld T., Kastepõld E. 1994. Estonia Matsalu 1993. Rõngastusaruanne nr. 24. Loodusvaatlusi II.

Kumari A., Jogi A. 1974. Lindude Rõngastamine Eesti NSV-s aastail 1956-1967. Abiks loodusevaatlejale 67.

Lindholm C.-G. 1978. The migration of the Great Tit Parus major across the Baltic Sea in the autumns of 1975 and 1976. Anser, Suppl. 3: 145-153.

Nowakowski J.K. 2001. Speed and synchronisation of autumn migration of the Great Tit (Parus major) along the eastern and the southern Baltic coast. Ring 23: 55-71.

Nowakowski J.K. 2002. Do numbers of Great Tits Parus major caught at ringing stations reflect the real intensity of passage? Ornis Svecica 12: 197-201.

Nowakowski J.K. 2003. Catch numbers at ringing stations is a reflection of bird migration intensity, as exemplified by autumn movements of the Great Tit (Parus major). Ring 25, 1-2: 3-15.

Nowakowski J.K., Vähätalo A.V. 2003. Is the Great Tit Parus major an irruptive migrant in North-east Europe? Ardea 91: 231-244.

Patapavičius R. 1982. Paukščiu žiedavimas Lietuvoje 1981 m. Lietuvos TSR Mokslų Akademijos Zoologijos IR. Vilnius.

Patapavičius R. 1983. Paukščiu žiedavimas Lietuvoje 1982 m. Lietuvos TSR Mokslų Akademijos Zoologijos IR. Vilnius.

Patapavičius R. 1986a. Paukščiu žiedavimas Lietuvoje 1983 m. Lietuvos TSR Mokslų Akademijos Zoologijos IR. Vilnius.

Patapavičius R. 1986b. Paukščiı žiedavimas Lietuvoje 1984 m. Lietuvos TSR Mokslų Akademijos Zoologijos IR. Vilnius.

Patapavičius R. 1986c. Paukščiu žiedavimas Lietuvoje 1985 m. Lietuvos TSR Mokslų Akademijos Zoologijos IR. Vilnius.

Patapavičius R. 1987. Paukščiu žiedavimas Lietuvoje 1986 m. Lietuvos TSR Mokslų Akademijos Zoologijos IR. Vilnius.

Patapavičius R. 1988. Paukščí žiedavimas Lietuvoje 1987 m. Lietuvos TSR Mokslų Akademijos Zoologijos IR. Vilnius.

Patapavičius R. 1989. Paukščiu žiedavimas Lietuvoje 1988 m. Lietuvos TSR Mokslų Akademijos Ekologijos Institutas. Vilnius. 
Rute J. 1976. On the speed of migration as observed with the Tit (genus Parus). Zool. Muz. Raksti 15: 34-49. Skuodis V., Kurpyté A. 1989. Paukščiu žiedavimas Lietuvoje 1960-1974 m. Lietuvos TSR Mokslų Akademijos Zoologijos IR. Vilnius.

Ulfstrand S. 1962. On the nonbreeding ecology and migratory movements of the Great Tit (Parus major) and the Blue Tit (Parus caeruleus) in southern Sweden. Vår Fågelv., Suppl. 3. 